\title{
PENERAPAN METODE TERM FREQUENCY INVERSE DOCUMENT FREQUENCY (TF-IDF) DAN COSINE SIMILARITY PADA SISTEM TEMU KEMBALI INFORMASI UNTUK MENGETAHUI SYARAH HADITS BERBASIS WEB (STUDI KASUS: SYARAH UMDATIL AHKAM)
}

\author{
Ria Melita $^{1}$, Victor Amrizal ${ }^{2}$, Hendra Bayu Suseno ${ }^{3}$, Taslimun Dirjam ${ }^{4}$ \\ 1.2Program Studi Teknik Informatika, Fakultas Sains dan Teknologi \\ Universitas Islam Negeri Syarif Hidayatullah Jakarta \\ ria.melita17@gmail.com, ersebros@gmail.com, hendra.bayu@uinjkt.ac.id, \\ taslimundirjam@uinjkt.ac.id
}

\begin{abstract}
ABSTRAK
Hadits merupakan sumber ajaran Islam di samping Al-Qur'an. Tanpa hadits, syari'at Islam tidak dapat dimengerti secara utuh dan tidak dapat dilaksanakan. Namun dewasa ini, tidak sedikit orang yang keliru dalam memahaminya, hal tersebut disebabkan oleh banyaknya orang yang memahami hadits sebatas mengandalkan teks lahiriyah saja. Salah satu hal yang dapat kita tempuh untuk mengetahui makna yang terkandung dalam hadits adalah dengan mempelajari syarah hadits guna meminimalisir kesalahan penafsiran terhadap suatu hadits. Sejauh ini aplikasi syarah hadits yang ada masih terbatas, yaitu dalam bahasa full arab yang tidak semua orang dapat memahaminya. Sedangkan untuk bahasa indonesia hanya ada lidwa dan arbain, namun masih sangat luas jangkauannya. Oleh karena itu, diperlukan jangkauan pemahaman dalam ilmu hadits dan dengan adanya sistem yang akan dibangun, maka akan memberikan solusi permasalahan tersebut, yaitu Sistem Temu Kembali Informasi yang dapat dimanfaatkan untuk mengetahui syarah hadits, karena dapat memberikan alternatif berupa metode similarity yang dapat digunakan untuk melakukan pencarian dokumen relevan dengan yang kita inginkan. Metode similiarity yang digunakan adalah cosine similarity dengan pembobotan kata menggunakan metode TFIDF dan menerapkan teks preprocessing terlebih dahulu untuk memperkecil term sehingga bisa mempercepat proses perhitungan term. Teks preprocessing tersebut meliputi tokenizing, stopword removal atau filtering, dan stemming. Hasil uji coba dengan pengujian confusion matrix didapatkan: recall $88.7 \%$, precision $100 \%$, accuracy $88,73 \%$, dan error rate $11,27 \%$.
\end{abstract}

Kata Kunci: syarah, hadits, cosine similarity, tf-idf

\begin{abstract}
Hadith is a source of Islamic teachings besides the Qur'an. Without using the hadith, the syari'at of Islam can not be fully understood and can not be implemented. But today, many people are mistaken in understanding it, it is caused by the many people who understand the hadith to rely on text lahiriyah only. One of the things that we can take to know the meaning contained in the hadith is to study syarah hadith in order to minimize misinterpretation of a hadith. So far the application of syarh hadith is still limited. Because so far the existing applications are still full Arab language that not everyone can understand it. As for the Indonesian language there are only lidwa and arbain, but still very wide reach. Therefore, we need a system for the solution of the problem, that is Information Retrieval System which can be utilized because it provides an alternative in the form of similarity method that can be used to search documents relevant to what we want. The similiarity method used is cosine similarity with word weighting using TFIDF method and applying preprocessing text first to minimize term so that it can speed up the term calculation process. The preprocessing text includes tokenizing, stopword removal or filtering, and stemming. The results of testing with confusion matrix test obtained: $88.7 \%$ recall, precision $100 \%$, accuracy $88.73 \%$, and error rate $11.27 \%$.
\end{abstract}

Keywords: syarah, hadith, cosine similarity, $t f-i d f$

http://dx.doi.org/10.15408/jti.v11i2.8623

Ria Melita, dkk: Penerapan Metode... 


\section{PENDAHULUAN}

\subsection{Latar Belakang}

Hadits merupakan sumber ajaran Islam disamping Al-Qur'an. Tanpa menggunakan hadits, syari' at Islam tidak dapat dimengerti secara utuh dan tidak dapat dilaksanakan. [1]. Hadits sebagai sumber hukum kedua setelah Al-Qur'an, memiliki otoritas dan posisi penting yang nampaknya sudah tidak perlu dipertanyakan lagi, karena selain sebagai penjelas (bayan) bagi otoritas wahyu Allah (Al-Qur'an) juga sebagai sumber hukum Islam kedua yang menjadi rujukan para fuqaha yaitu ahli fiqih atau hukum islam. [2].

Pentingnya posisi hadits tehadap AlQur'an turut menempatkan posisi Syarah Hadits sebagai sesuatu yang tidak dapat diabaikan. Teks-teks hadits yang ada menjadi penjelas atas teks-teks Al-Qur'an yang dianggap masih bersifat global. Syarah memegang peranan penting untuk menjelaskan hal-hal yang dianggap masih umum, sulit dipahami, terlihat bertentangan, maupun halhal yang menyimpan keganjilan dalam teksteks hadits. Syarah Hadits adalah keterangan tentang suatu maksud dalam suatu hadits. Tanpa keberadaan syarah hadits, susah kiranya untuk memahami makna sesungguhnya dari suatu hadits [3].

Hasil wawancara yang telah penulis lakukan dengan Bapak Fiqri Muhammad Fatkhi, MA. Selaku Ketua Program Studi Hadits Fakultas Ushuluddin UIN Syarif Hidayatullah Jakarta, didapatkan bahwa "saat ini tidak sedikit orang yang keliru dalam memahami hadits dikarenakan oleh beberapa faktor yang mempengaruhinya seperti memahami hadits sebatas teks lahiriyah hadits saja".

Menurut Bapak Fiqri, hal yang dapat kita tempuh untuk mengetahui makna yang terkandung dalam hadits adalah salah satunya dengan mempelajari syarah hadits, dimana mempelajari syarah hadits untuk mengetahui makna yang terkandung didalamnya ini sangat penting untuk dilakukan sepanjang diperoleh dari orang yang memiliki otoritas dibidang penjelasan hadits.

Merujuk pada penjelasan beliau, sejauh ini aplikasi syarah hadits yang ada masih terbatas, yaitu dalam bahasa full arab yang tidak semua orang dapat memahaminya. Sedangkan untuk bahasa indonesia sendiri baru ada lidwa dan arbain, namun masih sangat luas jangkauannya yaitu dari berbagai perawi dan tidak ada dalam bentuk softcopy untuk memudahkan dalam memahami suatu hadits.

Berdasarkan pemaparan diatas, untuk mengetahui syarah hadits guna meminima-lisir kesalahan penafsiran terhadap suatu hadits, maka penulis ingin melakukan penelitian dengan merancang suatu sistem temu kembali informasi untuk mengetahui syarah hadits dengan bahasa indonesia yang berpedoman pada kitab Taysirul 'Allam Syarah 'Umdatil Ahkam yang akan dibuat dengan menerapkan metode Term Frequency Inverse Document Frequency (TF-IDF) dan Cosine Similarity.

Taysirul 'Allam Syarah 'Umdatil Ahkam adalah kitab syarah yang sangat populer di kalangan penuntut ilmu di seluruh dunia, termasuk pesantren-pesantren di Indonesia yang merupakan kumpulan hadits-hadits riwayat imam Bukhari-Muslim - keduanya sudah sangat masyhur di telinga kaum Muslimin seantero dunia sebagai jaminan keshahihan suatu hadits.[4].

Sistem temu kembali informasi ini merupakan suatu sistem yang menemukan (retrieve) informasi yang sesuai dengan kebutuhan user berdasarkan query yang dimasukkan. Dengan begitu, penelitian ini diharapkan dapat memberikan output berupa syarah hadits yang sesuai ber-dasarkan input yang dimasukkan dengan menggunakan Metode Term Frequency Inverse Document Frequency (TF-IDF) dan Cosine Similarity. Metode Term Frequency Inverse Document Frequency (TF-IDF) ini merupakan suatu cara untuk memberikan bobot hubungan suatu kata (term) terhadap dokumen. Sedangkan, Metode cosine similarity merupakan metode untuk menghitung kesamaan antara dua buah objek yang dinyatakan dalam dua buah vector dengan menggunakan keywords (kata kunci) dari sebuah dokumen sebagai ukuran [5].

Metode tf-idf ini penulis gunakan, karena merupakan metode pembobotan kata yang terkenal efisien, mudah dan memiliki hasil yang akurat.[6]. Sedangkan Metode Cosine Similarity penulis gunakan dengan alasan bahwa, metode ini mempunyai nilai akurasi yang tinggi dimana kelebihan utama dari metode cosine similarity adalah tidak terpengaruh pada panjang pendeknya suatu dokumen. Sehingga, dengan melakukan perbandingan keyword yang dihasilkan, maka 
kedekatan antara item-pun dapat dipastikan. [7].

Penelitian terkait dengan menggunakan metode tf-idf dan cosine similarity ini telah dilakukan sebelumnya oleh Rizki Tri Wahyuni, Dhidik Prastiyanto, dan Eko Supraptono dalam jurnalnya yang berjudul " Penerapan Algoritma Cosine Similarity dan Pembobotan Term Frequency Inverse Document Frequency pada Sistem Klasifikasi Dokumen Skripsi” mengenai perancangan sistem yang dapat meng-klasifikasikan dokumen secara otomatis kedalam folder berbeda pada database agar lebih mudah dalam mengelola dokumen yang ada.

Penelitian yang dilakukan oleh Dewa Ayu, Arie Lumenta, dan Agustinus Jacobus dalam jurnalnya yang berjudul "Pengukuran Kemiripan Dokumen Teks Bahasa Indonesia Menggunakan Metode Cosine Similarity" yaitu penelitian yang mengukur kemiripan dokumen untuk mengetahui adanya plagiarisme terhadap suatu karya tulis.

Penelitian dengan judul "Sistem Temu Kembali Informasi pada Dokumen Teks Menggunakan Metode Term Frequency Inverse Document frequency" yang dilakukan oleh Dhony Syafe'i, Sukmawati, dan Nurdin Bahtiar, mengenai pembuatan suatu perangkat lunak yang dapat mencari dokumen-dokumen penulisan ilmiah yang relevan sesuai tingkat pembobotannya.

Dari ketiga penelitian terkait yang telah penulis sebutkan diatas, terdapat beberapa irisan yang penulis tekankan dalam penelitian tersebut yaitu dalam penggunaan stemming pada text preprocessing. Dimana penelitian yang dilakukan oleh Rizki Tri Wahyuni, dkk dan Dewa Ayu, dkk tidak melakukan stemming pada text preprocessing dan penelitian yang dilakukan oleh Dhony Syafe'i menggunakan Stemming dengan jenis Porter Stemmer model Fadhillah Z.Tala. Oleh karena itu, penulis menggunakan Stemming model Nazief dan Adriani pada text preprocessing untuk meningkatkan performa sistem yang akan dibuat, dimana stemming model ini merupakan stemming yang memiliki tingkat akurasi (presisi) lebih tinggi dibandingkan dengan stemming model lain. Penelitian yang penulis lakukan menggunakan metode yang sama yaitu term frequency inverse document frequency dan cosine similarity pada sistem temu kembali informasi, namun terdapat perbedaan yang mendasar dari semua penelitian yang ada yaitu bahwa penulis melakukan penerapan metode tersebut pada sistem temu kembali informasi untuk mengetahui syarah hadits yang belum pernah dilakukan sebelumnya.

Sistem temu kembali informasi ini akan dibuat dengan menggunakan aplikasi berbasis web dengan kelebihan tidak memerlukan proses instalasi, bersifat terpusat, dapat dijalankan di os manapun asalkan memiliki browser dan akses internet, dan tidak perlu spesifikasi komputer client yang tinggi.

Berdasarkan permasalahan diatas, maka penulis tertarik untuk melakukan penelitian dengan judul "Penerapan Metode Term Frequency Inverse Document Frequency (TfIdf) dan Cosine Similarity pada Sistem Temu Kembali Informasi untuk Mengetahui Syarah Hadits Berbasis Web (Studi Kasus: Syarah Umdatil Hakam)".

\subsection{Rumusan Masalah}

Berdasarkan latar belakang yang dikemukakan, maka rumusan masalah yang ada pada penelitian ini adalah:

1. Bagaimana menerapkan metode term frequency inverse document frequency (tfidf) dan cosine similarity pada sistem temu kembali informasi untuk mengetahui syarah hadits berbasis web?

2. Bagaimana menghitung nilai akurasi pada Stemming Nazief dan Adriani yang digunakan dalam text preprocessing?

\subsection{Tujuan Penelitian}

Tujuan dari penelitian ini adalah sebagai berikut:

1. Menerapkan metode term frequency inverse document frequency (tf-idf) dan cosine similarity pada sistem temu kembali informasi untuk mengetahui syarah hadits berbasis web (studi kasus: hadits shahih Bukhari-Muslim).

2. Menghitung nilai akurasi pada Stemming Nazief dan Adriani yang digunakan dalam text preprocessing.

\section{TINJAUAN PUSTAKA}

\subsection{Syarah Hadits}

Syarah hadits adalah suatu aktivitas penyingkapan atau penjelasan atas makna- 
makna dan pemahaman atas sesuatu yang disandarkan pada Rasulullah SAW baik yang berupa perkataan, perbuatan, ketetapan, maupun sifat-sifatnya. [8].

\subsection{Taysirul 'Allam Syarah Umdatil Ahkam}

Kitab Umdatil Ahkam ini merupakan pilihan dari atsar-atsar Nabi SAW paling shahih bersumber dari dua kitab agung; Shahih al-Bukhari dan Shahih Muslim yang dapat dijadikan rujukan dalam pembelajaran hadits bagi siapapun yang sudah mencapai tingkatan mahir, sekaligus tangga bagi pemula menuju kitab-kitab Islam yang diriwayatkan dari manusia terbaik, Rasulullah SAW.

Dibandingkan dengan kitab syarah lain seperti syarah Al-Allamah ahli ijtihad, dan Ibnu Daqiq Id yang beredar luas dimana metode pembahasan yang digunakan penulis rumit dan kuat, jauh diatas pemahaman sebagian besar para penuntut ilmu dan mereka yang mencari informasi, keutamaan dari kitab ini adalah menggunakan bahasa yang mudah dipahami, keterangannya tidak bertele-tele, ringkas, dan jelas bagian-bagiannya, agar permasalahan-permasalahan yang ada beserta penjelasannya tidak tumpang tindih dan bercampur, yang tentu saja akan membingungkan [9].

\subsection{Text Mining}

Text mining dapat didefinisikan secara luas sebagai suatu proses menggali informasi dimana seorang user berinteraksi dengan sekumpulan dokumen menggunakan tools analisis yang merupakan komponen-komponen dalam data mining yang salah satunya adalah kategorisasi. [10]

\subsection{Sistem Temu Kembali Informasi}

Information Retrieval (IR) merupakan bagian dari computer science yang berhubungan dengan pengambilan informasi dari dokumen-dokumen yang didasarkan pada isi dan konteks dari dokumen-dokumen itu sendiri. Information Retrieval merupakan suatu pencarian informasi (biasanya berupa dokumen) yang didasarkan pada suatu query (inputan user) yang diharapkan dapat memenuhi keinginan user dari kumpulan dokumen yang ada [11].

\subsection{Text Preprocessing}

Text Preprocessing merupakan tahapan dari proses awal terhadap teks untuk mempersiapkan teks menjadi data yang akan diolah lebih lanjut. Suatu teks tidak dapat diproses langsung oleh algoritma pencarian, oleh karena itu dibutuhkan preprocessing text untuk mengubah teks menjadi data numeric [12]. Proses ini terdiri dari beberapa tahap pembersihan dokumen seperti berikut [13]:

\section{a. Tokenizing}

Tokenizing adalah proses memecah dokumen menjadi kumpulan kata. Tokenization dapat dilakukan dengan menghilangkan tanda baca dan memisahkannya per-spasi. Tahapan ini juga menghilangkan karakter-karakter tertentu seperti tanda baca dan mengubah semua token ke bentuk huruf kecil (lower case).

\section{b. Stopword Removal atau Filtering}

Stopwords removal merupakan proses penghilangan kata tidak penting pada deskripsi melalui pengecekan kata-kata hasil parsing deskripsi apakah termasuk di dalam daftar kata tidak penting (stoplist) atau tidak.

\section{c. Stemming Nazief \& Adriani}

Stemming merupakan bagian yang tidak terpisahkan dalam Information Retrieval (IR). Tidak banyak algoritma yang dikhususkan untuk stemming bahasa Indonesia dengan berbagai keterbatasan didalamnya. Algoritma Porter misalnya, algoritma ini membutuhkan waktu yang relatif lebih singkat dibandingkan dengan stemming menggunakan algoritma Nazief dan Adriani, namun proses stemming menggunakan algoritma Porter memiliki persentase keakuratan lebih kecil dibandingkan dengan stemming menggunakan algoritma Nazief dan Adriani. Algoritma Nazief dan Adriani sebagai algoritma stemming untuk teks berbahasa Indonesia yang memiliki kemampuan persentase keakuratan lebih baik dari algoritma lainnya [14].

Langkah-langkah pada Algoritma Nazief \& Adriani adalah sebagai berikut[15]:

1. Kata yang belum di-stemming dicari pada kamus. Jika kata itu langsung ditemukan, berarti kata tersebut adalah kata dasar. Kata tersebut dikembalikan dan algoritma dihentikan.

2. Inflection Suffixes ("-lah", "-kah", "-ku", "-mu", atau "-nya") dibuang. Jika berupa partikel (“-lah", “-kah", "-tah", 
atau "-pun") maka langkah ini diulangi lagi untuk menghapus Possesive Pronouns ("-ku", "-mu", atau "- nya"), jika ada.

3. Hapus Derivation Suffixes (“-i", "-an”, atau "-kan"). Jika kata ditemukan di kamus, maka algoritma berhenti. Jika tidak maka ke langkah $3 \mathrm{a}$.

a. Jika "-an", telah dihapus dan huruf terakhir dari kata tersebut adalah "k", maka "-k" juga ikut dihapus. Jika kata tersebut ditemukan dalam kamus kata dasar maka algoritma berhenti. Jika tidak ditemukan maka lakukan langkah $3 \mathrm{~b}$.

b. Akhiran yang dihapus ("-i", “-an", atau "-kan") dikembalikan, lanjut ke langkah 4.

4. Hapus Derivation Prefix DP ("di-", "ke-", "se-", "me-", "be-", "pe-", "te") dengan iterasi maksimum adalah 3 kali.

a. Langkah 4 berhenti jika :

- Terjadi kombinasi awalan dan akhiran yang terlarang seperti pada Tabel 1 di bawah ini.

Tabel 1. Kombinasi awalan akhiran yang tidak diizinkan

\begin{tabular}{cc}
\hline Awalan & Akhiran yang tidak diizinkan \\
\hline be- & $-\mathrm{i}$ \\
di- & -an \\
ke- & $-\mathrm{i},-$-kan \\
me- & -an \\
se- & $-\mathrm{i},-$ kan \\
\hline
\end{tabular}

- Tiga awalan telah dihilangkan.

b.Tipe awalan ditentukan melalui langkah-langkah berikut:

1. Jika awalannya adalah : "di-", "ke-", atau "se-", maka tipe awalannya secara berturut-turut adalah "di-", "ke-", atau "se-".

2. Jika awalannya adalah "te-", "me-", "be-", atau "pe-", maka dibutuhkan sebuah proses tambahan untuk menentukan tipe awalannya.

3. Cari kata yang telah dihilangkan awalannya ini di dalam kamus. Apabila tidak ditemukan, maka langkah 4 diulangi kembali. Apabila ditemukan, maka keseluruhan proses berhenti.

5. Setelah tidak ada lagi imbuhan yang tersisa, maka algoritma ini dihentikan kemudian kata dasar tersebut dicari pada kamus, jika kata dasar tersebut ketemu berarti algoritma ini berhasil tapi jika kata dasar tersebut tidak ketemu pada kamus, maka dilakukan recoding.

6. semua langkah telah dilakukan tetapi kata dasar tersebut tidak ditemukan pada kamus juga maka algoritma ini mengembalikan kata yang asli sebelum dilakukan stemming.

\subsection{Term Frequency Inverse Document Frequency (Tf-Idf)}

Metode TF-IDF merupakan metode untuk menghitung bobot setiap kata yang paling umum digunakan pada information retrieval. Metode ini juga terkenal efisien, mudah dan memiliki hasil yang akurat[16].

Metode Term Frequency-Inverse Document Frequency (TF-IDF) adalah cara pemberian bobot hubungan suatu kata (term) terhadap dokumen. TF-IDF ini adalah sebuah ukuran statistik yang digunakan untuk mengevaluasi seberapa penting sebuah kata di dalam sebuah dokumen atau dalam sekelompok kata. Untuk dokumen tunggal tiap kalimat dianggap sebagai dokumen. Frekuensi kemunculan kata di dalam dokumen yang diberikan menunjukkan seberapa penting kata itu di dalam dokumen tersebut. Frekuensi dokumen yang mengandung kata tersebut menunjukkan seberapa umum kata tersebut. Bobot kata semakin besar jika sering muncul dalam suatu dokumen dan semakin kecil jika muncul dalam banyak dokumen. [17].

Pada algoritma TF-IDF digunakan rumus untuk menghitung bobot (W) masing masing dokumen terhadap kata kunci dengan rumus yaitu :

$$
\mathrm{Wdt}=\mathrm{tfdt} * \mathrm{Idft}
$$

Dimana:

$\mathrm{Wdt}=$ bobot dokumen ke-d terhadap kata ke-t tfdt = banyaknya kata yang dicari pada sebuah dokumen

Idft = Inversed Document Frequency $(\log$

$(\mathrm{N} / \mathrm{df}))$

$\mathrm{N}=$ total dokumen

$\mathrm{df}=$ banyak dokumen yang mengandung kata yang dicari.

\subsection{Cosine Similarity}

Cosine Similarity adalah ukuran kesamaan antara dua buah vektor dalam sebuah ruang dimensi yang didapat dari nilai 
cosinus sudut dari perkalian dua buah vektor yang dibandingkan karena cosinus dari 0 adalah 1 dan kurang dari 1 untuk nilai sudut yang lain, maka nilai similarity dari dua buah vektor dikatakan mirip ketika nilai dari cosine similarity adalah 1 [18].

Berikut adalah rumus cosine similarity; Persamaan.

Similarity $=\cos (\theta)=$

$\frac{Q \cdot D}{|Q \|| D \mid}=\frac{\sum_{i=\mathbf{1}}^{n} \text { (wqi x wdij) }}{\sqrt{\sum_{i=1}^{n}(w q i)^{2}} x \sqrt{\sum_{i=1}^{n}(w d i j)^{2}}}$

Keterangan :

$\mathrm{Q} \cdot \mathrm{D}=$ dot product antara vektor $\mathrm{Q}$ dan vektor

$\mathrm{D}$

$|\mathrm{Q}|=$ panjang vektor $\mathrm{Q}$

$|\mathrm{D}|=$ panjang vektor $\mathrm{D}$

$|\mathrm{Q} \| \mathrm{D}|=$ cross product antara $|\mathrm{Q}|$ dan $|\mathrm{D}|$

wqi $=$ bobot term pada query $\mathrm{ke}-\mathrm{i},=\mathrm{tf} \mathrm{x}$ idf

$w d i j=$ bobot term pada dokumen ke-i istilah

ke- $\mathrm{j}=\mathrm{tf} \mathrm{x}$ idf

$\mathrm{i}=$ jumlah term dalam kalimat.

$\mathrm{N}=$ jumlah vektor.

Penulis memilih menggunakan metode cosine similarity dikarenakan metode ini mempunyai nilai akurasi yang tinggi dimana menurut [19] kelebihan utama dari metode cosine similarity adalah tidak terpengaruh pada panjang pendeknya suatu dokumen. Sehingga, dengan melakukan perbandingan keyword yang dihasilkan, maka kedekatan antara itempun dapat dipastikan.

\subsection{Confusion Matrix}

Confusion Matrix adalah sebuah metode yang biasa digunakan untuk perhitungan akurasi. Dalam pengujian keakuratan hasil pencarian akan dievaluasi nilai recall, precision, accuracy, dan error rate. Dimana precision mengevaluasi kemampuan sistem untuk menemukan peringkat yang paling relevan, dan didefinisikan sebagai presentase dokumen yang di-retrieve dan benar-benar relevan terhadap query. Recall mengevaluasi kemampuan sistem untuk menemukan semua item yang relevan dari koleksi dokumen dan didefinisikan sebagai presentase dokumen yang relevan terhadap query. Accuracy merupakan perbandingan kasus yang diidentifikasi benar dengan jumlah seluruh kasus dan error rate merupakan kasus yang diidentifikasi salah dengan jumlah seluruh kasus [20].

Rumus confusion matrix adalah sebagai berikut:

Tabel 2. Rumus confusion matrix

\begin{tabular}{lll}
\hline \multirow{2}{*}{$\begin{array}{l}\text { Documen } \\
\mathrm{t}\end{array}$} & \multicolumn{2}{c}{ Nilai Sebenarnya } \\
\cline { 2 - 3 } $\begin{array}{l}\text { Retrieve } \\
\mathbf{d}\end{array}$ & True Positive (tp) & False Positive (fp) \\
\hline Not & Correct result & Unexpected result \\
Retrieve & False Negative & True Negative (tn) \\
d & fn) & Corect absence of \\
\hline
\end{tabular}

Keterangan:

- TP $($ True Positive $)=$ Jumlah prediksi yang benar dari data yang relevant.

- FP $($ False Positive $)=$ Jumlah prediksi yang salah dari data yang tidak relevant.

- FN (False Negative $)=$ Jumlah prediksi yang salah dari data yang tidak relevant.

- TN $($ True Negative $)=$ Jumlah prediksi yang benar dari data yang relevant.

Sehingga, rumusnya adalah sebagai berikut:

Persamaan

$$
\begin{aligned}
& \text { 1. Precision }=\frac{t p}{(t p+f p)} \quad \text { 3. Accuracy }= \\
& (t p+t n) \\
& \overline{(t p+f p+t n+f n)} \\
& \text { 2.Recall }=\frac{t p}{(t p+f n)} \quad \text { 4. Error rate }= \\
& (f n+t n) \\
& \overline{(t p+f p+t n+f n)}
\end{aligned}
$$

Sistem yang dikatakan baik adalah sistem yang memiliki nilai recall dan precision tinggi.

\section{METODOLOGI}

\subsection{Metode Pengumpulan Data}

Dalam melaksanakan penelitian ini diperlukan data dan informasi terkait yang nantinya akan digunakan sebagai bahan rujukan untuk pembuatan penelitian serta mendukung keabsahan pembahasan pada laporan penelitian. Metode pengumpulan data yang digunakan yaitu:

\section{Metode Studi Pustaka.}

Dalam metode ini penulis melakukan studi pustaka dengan pencarian data secara manual juga melakukan pencarian data secara online melalui browsing internet dan melakukan pembelajaran terhadap jurnal dan skripsi yang relevan sesuai dengan topik penelitian yang 
dijadikan sebagai bahan acuan dalam pembuatan penelitian.

Data yang didapatkan digunakan dalam penyusunan landasan teori, metodologi penelitian dan pengembangan sistem.

\section{Metode Wawancara}

Dalam metode wawancara ini penulis melakukan wawancara dengan Bapak Rifqi Muhammad Fatkhi, MA selaku Kepala Jurusan Program Studi Hadits Fakultas Ushuludin Universitas Islam Negeri Syarif Hidayatulllah Jakarta. Wawancara dilakukan 2 kali yaitu untuk mendukung permasalahan yang terkait, dan untuk pengujian sistem yang telah dibuat.

\subsection{Metode Pengembangan Sistem}

Dalam metode pengembangan system ini penulis menggunakan model Rapid Aplication Development (RAD) dengan tahapan sebagai berikut:

\section{Fase Perencanaan Syarat (Requirement Planning)}

Dalam fase ini penulis melakukan syarat-syarat perencanaan dengan langkah: Mengidentifikasi masalah, menganalisis solusi permasalahan, dan menganalisis kebutuhan sistem.

\section{Fase Workshop Desain (Design Workshop)}

Dalam fase ini penulis melakukan perancangan sistem, desain sistem dan pengkodean sistem.

\section{Fase Implementasi (Implementation)}

Fase ini merupakan fase terakhir setelah melalui fase-fase sebelumnya. Dimana dalam fase ini, hasil dari perancangan yang telah dilakukan akan diimplementasikan ke dalam sistem dengan langkah: Implementasi sistem, dan testing.

\section{HASIL DAN PEMBAHASAN}

Perancangan sistem proses yang ada adalah teks preprocessing terhadap dokumen dan query dengan menerapkan metode yang digunakan yaitu dengan metode tf-idf untuk pembobotan kata dan cosine similarity untuk menemukan dokumen dengan menghitung kedekatan antar dokumen. Penjelasannya sebagai berikut:

\subsection{Text Preprocessing}

Sebelum melakukan tahap teks preprocessing, yang harus dilakukan adalah menyimpan semua dokumen yang akan dicari dalam sebuah koleksi dokumen. Dimana dokumen ini merupakan koleksi hadits bahasa indonesia yang akan digunakan sebagai query beserta syarah-nya (sebagai dokumen relevan) yang akan diproses dan disimpan dalam database MySQL. Selanjutnya tahap teks preprocessing dokumen, akan dijelaskan prosesnya sebagai berikut:

\section{Tokenizing}

Proses yang berjalan saat tahap tokenizing, akan digambarkan dalam flowchart berikut:

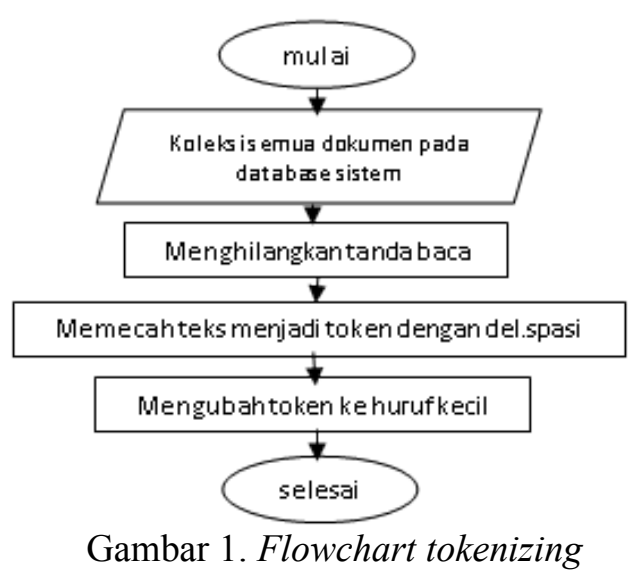

Gambar di atas menggambarkan proses yang dilakukan saat tahap tokenizing, dimana koleksi dokumen (query dan dokumen relevan) yang ada dalam database dilakukan penghilangan tanda baca, pemecahan teks menjadi token dengan delimeter spasi, dan pengubahan token yang terbentuk menjadi huruf kecil. Penerapan tokenizing penulis berikan pada salah satu contoh hadits dalam bab thaharah, dimana hadits yang diproses sebagai query harus memenuhi syarat untuk dapat diproses sistem, yaitu menggunakan hadits dengan struktur yang lengkap (terdapat sanad dan matan) karena tanpa salah satunya maka hadits tidak dapat diproses (untuk membedakan antara aplikasi hadits dengan aplikasi pengolahan teks yang lain). Hasil dari penerapan proses tokenizing adalah sebagai berikut:

Tabel 3. Hasil tokenizing

\begin{tabular}{cl}
\hline \multicolumn{1}{c}{ Sebelum } & \multicolumn{1}{c}{ Sesudah } \\
Tokenizing & dari \\
Dari Abu Hurairah ia & Henala \\
berkata, "Rasulullah & abu \\
SAW bersabda: "Allah & hurairah
\end{tabular}




\begin{tabular}{ll} 
tidak menerima sholat & ia \\
seseorang di antara & berkata \\
kallian ketika & rasulullah \\
berhadats, hingga ia & saw \\
berwudhu'." & bersabda \\
& allah \\
& tidak \\
& menerima \\
& shalat \\
& seseorang \\
& diantara \\
& kalian \\
& ketika \\
& berhadats \\
& hingga \\
& ia \\
& berwudhu \\
\hline
\end{tabular}

\section{Stopword Removal atau Filtering}

Proses yang berjalan saat tahap stopword removal atau filtering, akan digambarkan dalam flowchart berikut:

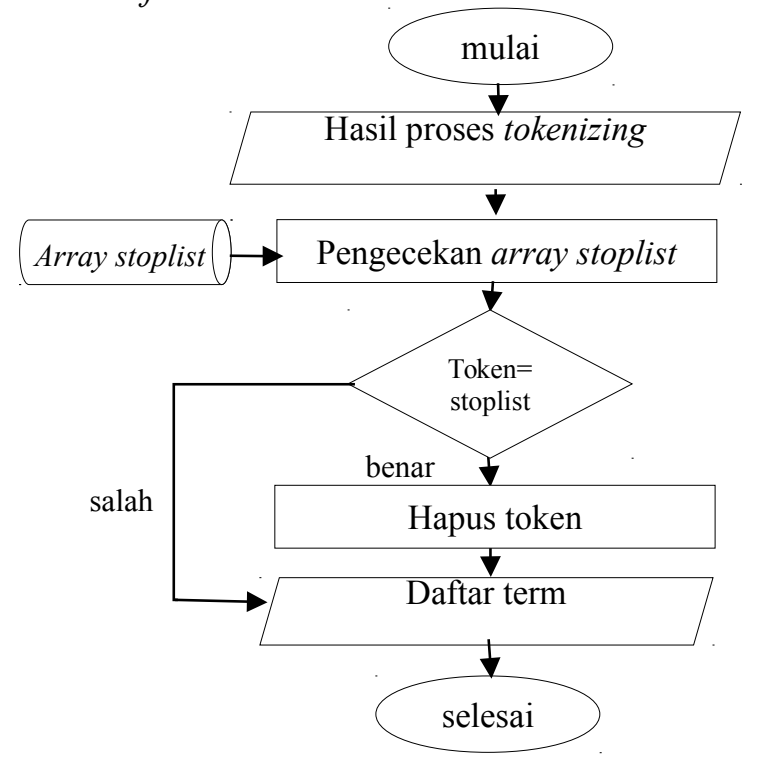

Gambar 2. Flowchart stopword removal

Gambar di atas menggambarkan proses yang dilakukan saat tahap stopword removal atau filtering, dimana hasil dari proses tokenizing yang dilakukan sebelumnya, akan di cocokan dengan array stoplist yang ada, apabila token yang dicek merupakan stoplist maka token akan dihapus, apabila token bukan termasuk stoplist maka token akan dibiarkan tetap ada. Contoh hasil penerapan stopword removal atau filtering adalah sebagai berikut:

Tabel 4. Hasil stopword removal

\begin{tabular}{cc}
\hline $\begin{array}{c}\text { Sesudah } \\
\text { Tokenizing }\end{array}$ & $\begin{array}{c}\text { Sesudah Proses } \\
\text { Stopword }\end{array}$ \\
\hline dari & -
\end{tabular}

$\mathrm{abu}$

hurairah

ia

berkata

rasulullah

saw

bersabda

allah

tidak

menerima

shalat

seseorang

diantara

kalian

ketika

berhadats

hingga

ia

berwudhu

$\mathrm{abu}$

hurairah

rasulullah

saw

bersabda

allah

menerima

shalat

seseorang

kalian

berhadats

$-$

berwudhu

\section{Stemming Nazief Adriani}

Adapun algoritma stemming yang akan digunakan yaitu algoritma stemming Nazief \& Adriani, dimana stemming jenis ini merupakan stemming yang memiliki tingkat akurasi (presisi) lebih tinggi dari jenis stemming yang lain. Proses yang berjalan saat tahap stemming, akan digambarkan dalam flowchart berikut:

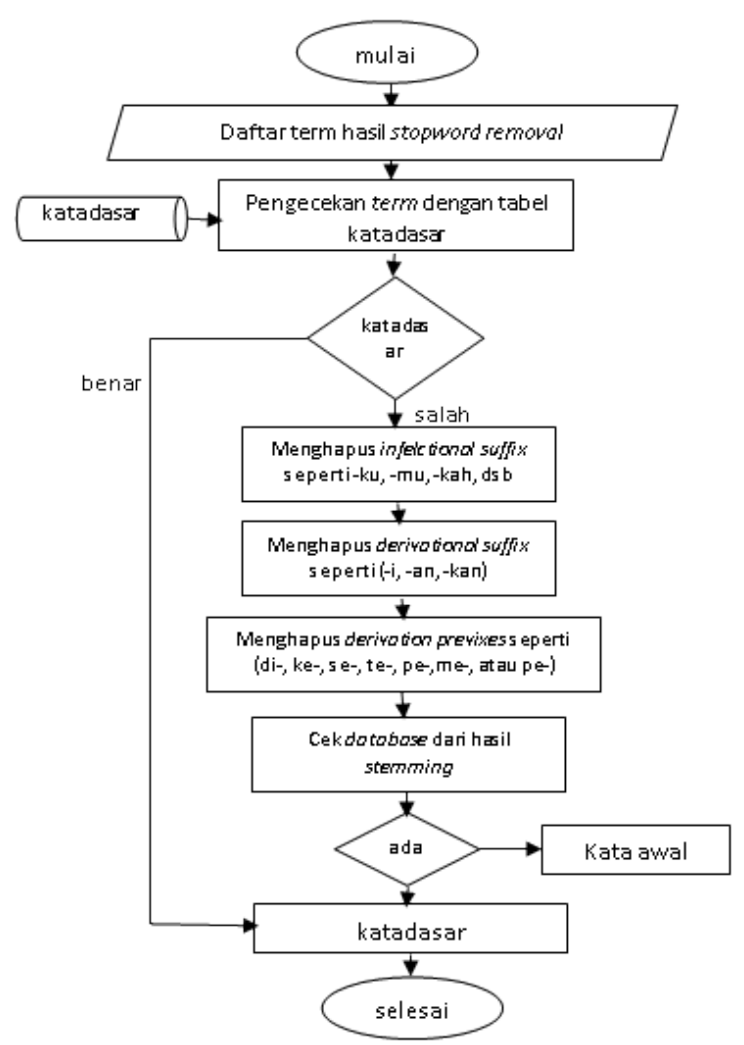

Gambar 3. Flowchart stemming 
Gambar di atas menggambarkan proses yang dilakukan saat tahap stemming, dimana term hasil dari proses sebelumnya dilakukan pengecekan terhadap database kata dasar apakah term sudah kata dasar atau kata berimbuhan. Apabila term merupakan kata berimbuhan maka akan dilakukan stemming dengan melalui 3 tahapan yaitu menghapus inflection suffix (seperti -ku, -mu, -kah, dsb), menghapus derivation suffix (seperti -i, -an, atau -kan), dan menghapus derivation prefix (seperti di-, ke-,se-, dsb). Hasil dari proses stemming ini akan dilanjutkan dengan tahap berikutnya untuk dilakukan pembobotan kata menggunakan algoritma tf-idf.

Hasil stemming dari algoritma Nazief Adriani adalah sebagai berikut:

Tabel 5. Hasil stemming

\begin{tabular}{cc}
\hline Sesudah Proses Stopword & Hasil Stemming \\
\hline abu & abu \\
hurairah & hurairah \\
rasulullah & rasulullah \\
saw & saw \\
bersabda & sabda \\
allah & allah \\
menerima & terima \\
shalat & shalat \\
seseorang & orang \\
kalian & kalian \\
berhadats & hadats \\
berwudhu & wudhu \\
\hline
\end{tabular}

\subsection{Pembobotan Kata (Tf-Idf)}

Setelah tahap teks preprocessing selesai, tahap selanjutnya adalah pembobotan kata (term). Dalam pembobotan kata (term) ini, setiap kata yang telah melewati proses preprocessing, akan di-parsing terlebih dahulu dan disimpan dalam database, kemudian dihitung jumlah kemunculan setiap katanya. Pada proses mulai cata (TF-IDF) akan digambarkan dararx forchart berikut:

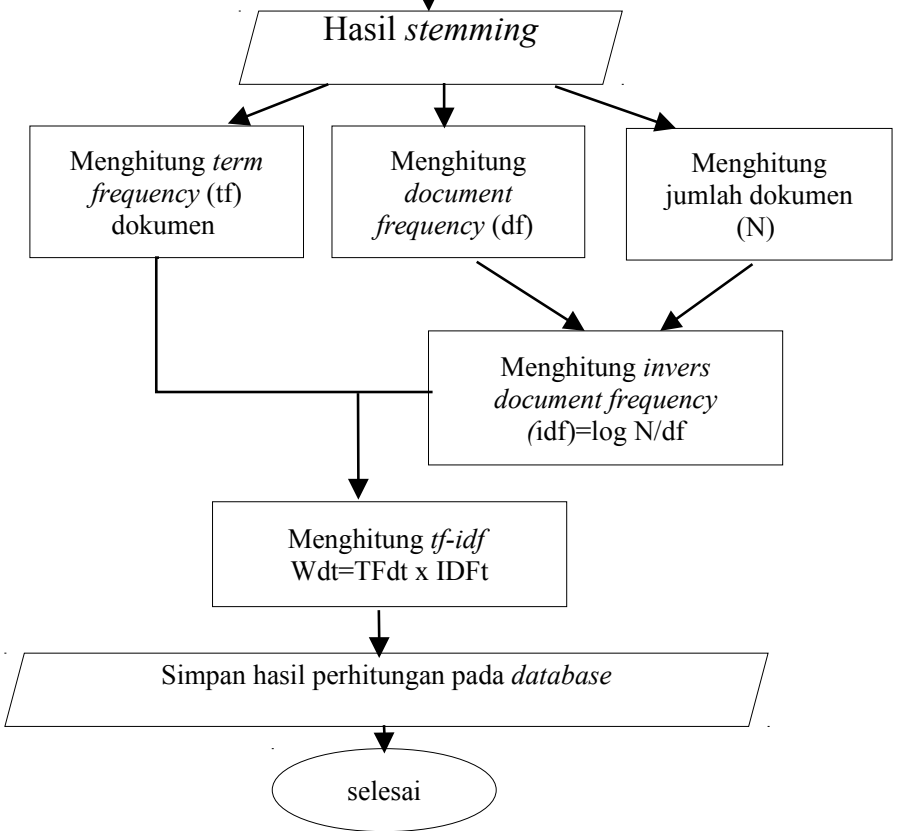

\section{Gambar 4. Flowchart Tf-Idf}

Gambar di atas menggambarkan tahap pembobotan kata dengan menggunakan metode term frequency inverse document frequency (TF-IDF), dimana daftar term hasil stemming dilakukan perhitungan untuk mengetahui bobot perkata dengan menghitung jumlah term frequency dokumen (tf) terlebih dahulu, kemudian menghitung nilai jumlah dokumen yang memiliki term (df), dan selanjutnya menghitung nilai idf dengan rumus $\log =\mathrm{N} / \mathrm{df}$, dimana $\mathrm{N}$ merupakan jumlah seluruh dokumen yang ada. Setelah nilai TF dan IDF sudah didapat, maka langkah terakhir adalah menentukan bobot kata dengan mengalikan TF dan IDF dengan rumus $\mathrm{Wdt}=\mathrm{TFdt} \quad \mathrm{x}$ IDFt. Hasil dari proses perhitungan ini disimpan dalam database dan akan dilanjutkan dengan tahap berikutnya untuk dilakukan perhitungan cosine similarity yang merupakan tahap akhir proses.

Contoh perhitungan pembobotan kata dalam penelitian ini menggunakan dokumen yang telah dilakukan teks preprocessing diatas (sebagai query) terhadap dua dokumen output untuk mengetahui kemiripannya, seperti berikut:

Diketahui : query $=>$ Dari Abu Hurairah ia berkata, "Rasulullah SAW bersabda: 'Allah tidak menerima sholat seseorang di antara kallian ketika berhadats, hingga ia berwudhu'."

Dimana terdapat 2 dokumen sebagai berikut:

\section{Tabel 6. Dokumen output}

d1 -Shalat orang yang berhadats tidak diterima, sampai ia bersuci dari hadats besar dan kecil.

-Hadats membatalkan wudhu, dan membatalkan shalat jika terjadi di selaselanya.

-Maksud tidak diterima dalam hadits ini adalah shalatnya tidak sah.

-Hadits ini menunjukkan, thaharah adalah syarat sah shalat. 
d2 -Wajib memerhatikan anggota-anggota wudhu dan tidak boleh mengabaikan sedikitpun diantaranya.

-Ancaman keras bagi yang tidak baik dalam berwudhu.

-Kedua kaki wajib dibasuh saat berwudhu, seperti disebutkan dalam banyak dalil shahih dan ijmak umat.
Pembahasan: sebelum dilakukan pembobotan kata antara query dan dokumen yang harus dilakukan adalah melakukan teks preprocessing terhadap semua dokumen yang akan diproses terlebih dahulu agar kata siap untuk dilakukan pembobotan.

Setelah preprocessing maka hasil perhitungan tf-idf adalah sebagai berikut:

Tabel 7. Perhitungan Tf-Idf

\begin{tabular}{|c|c|c|c|c|c|c|c|c|c|}
\hline \multirow{3}{*}{ term } & \multicolumn{3}{|c|}{ tf } & \multirow[t]{3}{*}{ df } & \multicolumn{2}{|c|}{ Idf } & \multicolumn{3}{|c|}{$\mathbf{W d t}=\mathbf{t f _ { \text { dt } }} \mathbf{X} \mathbf{i d f}_{\mathrm{t}}$} \\
\hline & \multirow[b]{2}{*}{$\mathbf{q}$} & & & & \multirow{2}{*}{\multicolumn{2}{|c|}{$\begin{array}{r}\text { Log } \\
\text { (N/df) }\end{array}$}} & & & \\
\hline & & d1 & d2 & & & & \multicolumn{2}{|c|}{ d1 } & d2 \\
\hline abai & & & & 1 & 1 & 0,477 & 0 & 0 & 0,477 \\
\hline abu & 1 & & & & 1 & 0,477 & 0,477 & 0 & 0 \\
\hline allah & 1 & & & & 1 & 0,477 & 0,477 & 0 & 0 \\
\hline ancaman & & & & 1 & 1 & 0,477 & 0 & 0 & 0,477 \\
\hline anggota & & & & 1 & 1 & 0,477 & 0 & 0 & 0,477 \\
\hline baik & & & & 1 & 1 & 0,477 & 0 & 0 & 0,477 \\
\hline banyak & & & & 1 & 1 & 0,477 & 0 & 0 & 0,477 \\
\hline basuh & & & & 1 & 1 & 0,477 & 0 & 0 & 0,477 \\
\hline batal & & 2 & & & 2 & 0,176 & 0 & 0,352 & 0 \\
\hline besar & & 1 & & & 1 & 0,477 & 0 & 0,477 & 0 \\
\hline dalil & & & & 1 & 1 & 0,477 & 0 & 0 & 0,477 \\
\hline dua & & & & 1 & 1 & 0,477 & 0 & 0 & 0,477 \\
\hline hadats & 1 & 3 & & & 4 & 0,125 & 0,125 & 0,375 & 0 \\
\hline hadits & & 2 & & & 2 & 0,176 & 0 & 0,352 & 0 \\
\hline hati & & & & 1 & 1 & 0,477 & 0 & 0 & 0,477 \\
\hline hurairah & 1 & & & & 1 & 0,477 & 0,477 & 0 & 0 \\
\hline ijmak & & & & 1 & 1 & 0,477 & 0 & 0 & 0,477 \\
\hline kaki & & & & 1 & 1 & 0,477 & 0 & 0 & 0,477 \\
\hline kalian & 1 & & & & 1 & 0,477 & 0,477 & 0 & 0 \\
\hline$\overline{\text { kecil }}$ & & 1 & & & 1 & 0,477 & 0 & 0,477 & 0 \\
\hline keras & & & & 1 & 1 & 0,477 & 0 & 0 & 0,477 \\
\hline maksud & & 1 & & & 1 & 0,477 & 0 & 0,477 & 0 \\
\hline orang & 1 & & & 1 & 2 & 0,176 & 0,176 & 0 & 0,176 \\
\hline rasulullah & 1 & & & & 1 & 0,477 & 0,477 & 0 & 0 \\
\hline sabda & 1 & & & & 1 & 0,477 & 0,477 & 0 & 0 \\
\hline sah & & 2 & & & 2 & 0,176 & 0 & 0,352 & 0 \\
\hline$\underline{\text { saw }}$ & 1 & & & & 1 & 0,477 & 0,477 & 0 & 0 \\
\hline sedikit & & & & 1 & 1 & 0,477 & 0 & 0 & 0.477 \\
\hline sela & & 1 & & & 1 & 0,477 & 0 & 0,477 & 0 \\
\hline shahih & & & & 1 & 1 & 0,477 & 0 & 0 & 0,477 \\
\hline shalat & 1 & 4 & & & 5 & 0,221 & 0,221 & 0,884 & 0 \\
\hline suci & & 1 & & & 1 & 0,477 & 0 & 0,477 & 0 \\
\hline syarat & & 1 & & & 1 & 0,477 & 0 & 0,477 & 0 \\
\hline terima & 1 & 2 & & & 3 & 0 & 0 & 0 & 0 \\
\hline thaharah & & 1 & & & 1 & 0,477 & 0 & 0,477 & 0 \\
\hline tunjuk & & 1 & & & 1 & 0,477 & 0 & 0,477 & 0 \\
\hline umat & & & & 1 & 1 & 0,477 & 0 & 0 & 0,477 \\
\hline wajib & & & & 1 & 1 & 0,477 & 0 & 0 & 0,477 \\
\hline wudhu & 1 & 1 & & 3 & 5 & 0,221 & 0,221 & 0,221 & 0,663 \\
\hline
\end{tabular}

\subsection{Cosine Similarity}

Setelah melakukan pembobotan dokumen terhadap term dengan menggunakan perhitungan tf-idf, langkah terakhir yang dilakukan untuk menemukan dokumen yang relevan dengan query adalah menghitung 
kemiripan antar dua dokumen dengan menggunakan rumus cosine similarity yang akan dijelaskan dalam flowchart berikut:

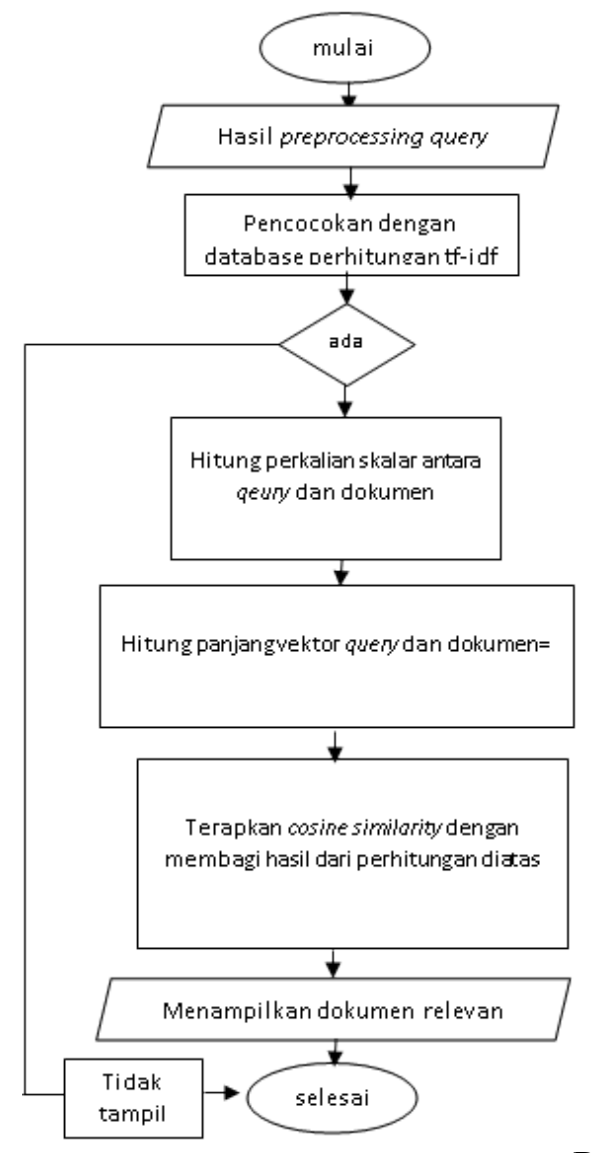

Gambar 5. Flowchart cosine similarity

Gambar di atas menggambarkan proses untuk menemukan dokumen yang relevan dengan query user menggunakan metode cosine similarity, dimana query yang dimasukkan user dilakukan tahap preprocessing yang hasilnya dicocokan dengan database bobot yaitu hasil perhitungan tf-idf, apabila term ditemukan maka akan dihitung perkalian skalar antara term query dengan dokumen dengan rumus wqi $\mathrm{x}$ wdij, selanjutnya yaitu menghitung nilai panjang setiap dokumen termasuk query dengan mengkuadratkan bobot query dan bobot dokumen, jumlahkan nilai kuadrat dan selanjutnya diakarkan. Terakhir, membagi hasil dari perkalian skalar dan hasil panjang vektor yang sudah dihitung untuk menemukan hasil kemiripan antara query dengan dokumen, lalu sistem akan menampilkan dokumen yang relevan dengan query berdasarkan hasil perhitungan kemiripan dengan cosine similarity tersebut.

Contoh perhitungan berdasarkan hasil dari pembobotan kata yang telah dilakukan sebelumnya, untuk mengetahui kemiripan query dengan d1 yang nanti akan dibandingkan dengan $\mathrm{d} 2$, adalah sebagai berikut:

Tabel 8. Perhitungan cosine similarity

\begin{tabular}{lccccc}
\hline \multicolumn{1}{c}{ term } & \multicolumn{2}{c}{$\mathrm{wq}_{\mathrm{i}} \times \mathrm{wd}_{\mathrm{ij}}$} & \multicolumn{3}{c}{ Panjang vektor q dan } \\
$\mathrm{d} 1, \mathrm{~d} 2$
\end{tabular}




\begin{tabular}{|c|c|c|c|c|c|}
\hline batal & 0 & 0 & 0 & 0,124 & 0 \\
\hline besar & 0 & 0 & 0 & 0,227 & 0 \\
\hline dalil & 0 & 0 & 0 & 0 & 0,227 \\
\hline dua & 0 & 0 & 0 & 0 & 0,227 \\
\hline hadats & 0,046 & 0 & 0,015 & 0,14 & 0 \\
\hline hadits & 0 & 0 & 0 & 0,124 & 0 \\
\hline hati & 0 & 0 & 0 & 0 & 0,227 \\
\hline hurairah & 0 & 0 & 0,227 & 0 & 0 \\
\hline ijmak & 0 & 0 & 0 & 0 & 0,227 \\
\hline kaki & 0 & 0 & 0 & 0 & 0,227 \\
\hline kalian & 0 & 0 & 0,227 & 0 & 0 \\
\hline kecil & 0 & 0 & 0 & 0,227 & 0 \\
\hline keras & 0 & 0 & 0 & 0 & 0,227 \\
\hline maksud & 0 & 0 & 0 & 0,227 & 0 \\
\hline orang & 0 & 0,03 & 0,03 & 0 & 0,03 \\
\hline rasulullah & 0 & 0 & 0,227 & 0 & 0 \\
\hline$\underline{\text { sabda }}$ & 0 & 0 & 0,227 & 0 & 0 \\
\hline sah & 0 & 0 & 0 & 0,124 & 0 \\
\hline$\underline{\text { saw }}$ & 0 & 0 & 0,227 & 0 & 0 \\
\hline sedikit & 0 & 0 & 0 & 0 & 0.227 \\
\hline sela & 0 & 0 & 0 & 0,227 & 0 \\
\hline shahih & 0 & 0 & 0 & 0 & 0,227 \\
\hline shalat & 0,195 & 0 & 0,048 & 0,781 & 0 \\
\hline suci & 0 & 0 & 0 & 0,227 & 0 \\
\hline syarat & 0 & 0 & 0 & 0,227 & 0 \\
\hline terima & 0 & 0 & 0 & 0 & 0 \\
\hline thaharah & 0 & 0 & 0 & 0,227 & 0 \\
\hline tunjuk & 0 & 0 & 0 & 0,227 & 0 \\
\hline umat & 0 & 0 & 0 & 0 & 0,227 \\
\hline wajib & 0 & 0 & 0 & 0 & 0,227 \\
\hline wudhu & 0,048 & 0,146 & 0,048 & 0,048 & 0,439 \\
\hline \multicolumn{3}{|c|}{$\begin{array}{c}\text { Jumlahkan hasil perkalian } \\
\text { diatas }\end{array}$} & \multicolumn{3}{|c|}{$\begin{array}{l}\text { Jumlahkan hasil } \\
\text { kuadrat diatas }\end{array}$} \\
\hline & 0,289 & 0,176 & 1.73 & 3.157 & 3.874 \\
\hline & & & \multicolumn{3}{|c|}{$\begin{array}{c}\text { Akarkan hasil } \\
\text { penjumlahan di atas }\end{array}$} \\
\hline & & & 1,315 & 1,776 & 1,968 \\
\hline
\end{tabular}

Setelah diketahui nilai dari masing-masing query dan dokumen, selanjutnya adalah dengan menerapkan rumus cosine similarity sebagai berikut:

$$
\begin{aligned}
& \text { 1. Cos } \\
& \text { (q, } \quad \mathrm{d} 1) \\
& \sum_{i=1}^{n}(\text { wqi x wd1 }) \\
& \begin{array}{c}
\sqrt{\sqrt{\sum_{i=\mathbf{1}}^{n}(w q i)^{2}} \times \sqrt{\sum_{i=\mathbf{1}}^{n}(w d \mathbf{1})^{2}}} \\
=\frac{0,28 \mathbf{9}}{1,315 \times 1,776}=\frac{0,28 \mathbf{9}}{2,335}= \\
0,123
\end{array}
\end{aligned}
$$

2. $\operatorname{Cos}$

(q,

$$
\text { d2) }
$$

$\sum_{i=1}^{n}(\mathbf{w q i} \mathbf{x} \mathbf{w d} 2)$

$$
\sqrt{\sum_{i=\mathbf{1}}^{n}(w q i)^{2}} \times \sqrt{\sum_{i=\mathbf{1}}^{n}(w d \mathbf{2})^{2}}
$$

$$
\begin{aligned}
& =\frac{0,176}{1,315 \times 1,968}=\frac{0,176}{2,588}= \\
& 0,068
\end{aligned}
$$

Berdasarkan hasil dari perhitungan cosine similarity diatas, hasil dari persamaan antara query dan d1 adalah 0,123 sedangkan hasil dari persamaan antara query dan $\mathrm{d} 2$ adalah 0,068. Maka dapat disimpulkan bahwa dokumen yang terdekat dengan query adalah dokumen 1 (d1). Hal tersebut dikarenakan hukum cosine similarity adalah semakin besar nilai cosinus (maksimal 1) maka semakin mirip dokumen dengan yang dibandingkan. Oleh karena itu, yang lebih mirip dengan query dan menjadi output dari query adalah d1 karena lebih mendekati angka 1 dibandingkan dengan dokumen 2 (d2). 


\subsection{Hasil Penelitian}

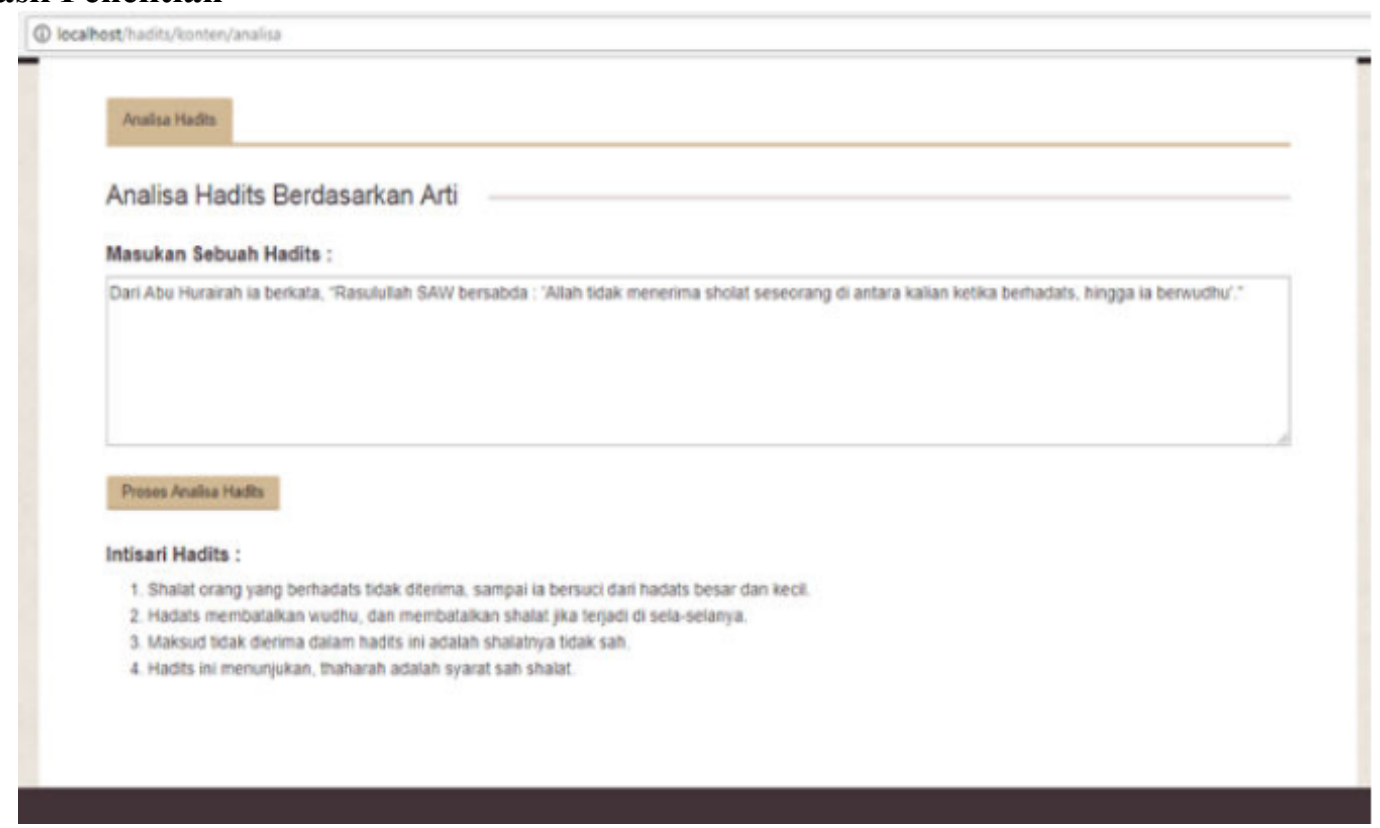

Gambar 6. Halaman analisis syarah

Gambar di atas merupakan tampilan dari halaman analisis hadits yang muncul ketika user mengklik tombol analisis hadits untuk melakukan proses analisis yaitu dengan mengisi hadits dalam Bahasa Indonesia dengan lengkap (sanad dan matan) pada kolom yang tersedia lalu setelah klik tombol proses analisis hadits maka akan muncul syarah hadits yang benar sesuai dengan hadits yang dimasukkan, sistem tidak akan memberikan output apabila hadits yang diinputkan tidak mengandung salah satu struktur hadits (sanad atau matan).

\subsection{Pengujian}

\section{Pengujian Stemming}

Adapun algoritma stemming yang digunakan dalam penelitian ini adalah algoritma Nazief \& Adriani, dimana stemming jenis ini merupakan stemming yang memiliki tingkat akurasi (presisi) lebih tinggi dari jenis stemming yang lain. Namun, pada proses stemming algoritma ini, penulis menemukan beberapa kata yang tidak berhasil distemming pada saat melakukan analisis secara manual, kata yang gagal di-stemming tersebut terjadi karena proses penghilangan imbuhan (akhiran) yang dilakukan terlebih dahulu setelah itu baru penghilangan awalan sehingga terjadi overstemming, lalu tidak adanya beberapa aturan dalam stemming nazief adriani seperti pe- +- ng, dan ter- sehingga untuk beberapa kata dengan aturan tersebut tidak berhasil distemming (kata tidak berubah), juga beberapa aturan yang masih belum berhasil mengembalikan kata ke dalam bentuk kata dasarnya. Contoh beberapa kata yang gagal dilakukan stemming terlihat dalam Tabel 9 di bawah ini: 
Tabel 9. Contoh hasil stemming yang kurang tepat

\begin{tabular}{cccc}
\hline Id & Token Awal & $\begin{array}{c}\text { Hasil } \\
\text { Stemming }\end{array}$ & $\begin{array}{c}\text { Hasil se- } \\
\text { harusnya }\end{array}$ \\
\hline $\mathbf{3 6}$ & dinikahinya & nikahi & nikah \\
$\mathbf{9 1}$ & diampuni & mpuni & ampuni \\
$\mathbf{2 3 6}$ & memberkahi & ber & berkah \\
$\mathbf{1 8 9 7}$ & sejumlah & sejum & jumlah \\
$\mathbf{2 2 2 6}$ & setelah & sete & telah \\
$\mathbf{2 5 2 0}$ & melakukan & laku & lakukan \\
$\mathbf{2 8 7 5}$ & melangkah & lang & langkah \\
$\mathbf{4 6 9 1}$ & memisah & misah & pisah \\
$\mathbf{2 1 2 8}$ & memerintah & merintah & perintah \\
$\mathbf{4 0 6 6}$ & terlimpah & terlimpah & limpah \\
$\mathbf{4 1 6 2}$ & terpuji & terpuji & puji \\
$\mathbf{4 3 7 2}$ & terakhir & terakhir & akhir \\
$\mathbf{4 7 5 3}$ & termasuk & termasuk & masuk \\
$\mathbf{3 7 2 3}$ & pengendara & pengendara & kendara \\
$\mathbf{4 0 6 2}$ & pengagungan & pengagungan & agung \\
\hline
\end{tabular}

Selain itu, pada kata yang merupakan bahasa asing atau nomor, tidak dilakukan stemming, hal ini dikarenakan cara kerja yang pertama dari algoritma Nazief Adriani adalah dengan melakukan pengecekan apakah kata yang akan di-stemming terdapat pada kamus yang tersedia atau tidak, jika iya maka akan dilakukan stemming, tapi jika tidak ada maka kata akan dianggap sebagai root word atau sebagai kata asal, sehingga kata asing dan nomor seperti: Musyik, qirath, jihad, mutalaffiat, khadaq,itikaf, shaum, qadha, haruriyah, istihadhah, istinja, madzi, khitan, junub, syafaat, subhanallah, jinabat, saw, rasulullah, $1,2,3,4,5$ dan sebagainya akan tetap menjadi seperti asalnya.

Berdasarkan analisis hasil stemming di atas, untuk mengetahui tingkat ke akuratan Stemming dengan Algoritma Nazief Adriani ini maka akan dihitung nilai persentase antara kata yang gagal di-stemming dengan yang berhasil. Total token yang ada pada database hasil preprocessing adalah 6.983, namun dalam 6.983 itu terdapat banyak pengulangan beberapa token, sehingga untuk pehitungan hasil stemming kata yang terbentuk hanya berjumlah 2.051. Untuk itu, hasil dari akurasi stemming Nazief Adriani adalah sebagai berikut:

1. Prosentase gagal $=\frac{186}{2051} \times 100 \%=9,07 \%$

2. Prosentase berhasil $=$ $\frac{1865}{2051} \times 100 \%=90,93 \%$

\section{Pengujian Sistem}

Dalam fase testing ini untuk melakukan pengujian sistem, penulis menggunakan pengujian confusion matrix yang biasa digunakan dalam perhitungan akurasi pada suatu sistem temu kembali informasi untuk mengevaluasi seberapa baik kemampuan sistem dalam pencarian dokumen. Pengujian sistem ini adalah dengan melakukan percobaan sebanyak 204 kali menggunakan query terhadap 204 dokumen yang ada dalam database. Query yang digunakan adalah query yang memiliki jumlah dokumen relevan masing-masing 1 untuk masing-masing query. Artinya, satu query hanya relevan dengan satu dokumen dimana dokumen tersebut merupakan syarah hadits yang relevan berdasarkan query yang dimasukkan.

Setelah melakukan percobaan terhadap 204 dokumen dengan query tersebut, didapatkan hasil benar yang ditemukan berjumlah 181 dokumen yang ditemukan relevan (sesuai dengan query), dan ditemukan 23 dokumen yang ditemukan tidak relevan (tidak sesuai dengan query). Oleh karena itu, maka hasil pengujian confusion matrix sesuai dengan rumus yang telah dibahas pada point 2.8 Tabel 2 adalah sebagai berikut:
1. Precision $=\frac{181}{(181+0)} \times 100 \%=100 \%$
181
2. Recall $=\overline{(181+23)} \times 100 \%=88,7 \%$ 

3. Accuracy $=\frac{(181+0)}{(181+0+0+23)} \times 100 \%=$ $88,73 \%$ $11,27 \%$

\section{PENUTUP}

\subsection{Kesimpulan}

Berdasarkan rumusan masalah yang telah dikemukakan, maka kesimpulan dalam penelitian ini adalah bahwa metode term frequency inverse document frequency (tf-idf) dan cosine similarity telah berhasil diterapkan dalam sistem dengan baik dimana sistem dapat memberikan output berupa dokumen yang relevan yaitu syarah hadits sesuai dengan query yang di-input kan, dengan melalui 3 tahapan teks preprocessing yaitu tokenizing, stopword removal atau filtering, dan stemming. Hasil pengujian stemming model Nazief Adriani yang telah dilakukan menunjukkan hasil akurasi sebesar $90,93 \%$ yang menyatakan bahwa stemming model ini memiliki tingkat akurasi yang tinggi. Kemudian, pengujian sistem yang dilakukan dengan menggunakan confusion matrix dalam penelitian ini didapatkan nilai precision $100 \%$, recall $88,7 \%$, accuracy $88,73 \%$, dan error rate $11,27 \%$. Sehingga, sistem dapat dikatakan baik, dikarenakan sistem yang baik adalah sistem yang memiliki nilai recall dan precision tinggi serta tingkat akurasi yang tinggi pula.

\subsection{Saran}

Untuk pengembangan selanjutnya, maka saran-saran yang dapat penulis berikan adalah sebagai berikut:

1. Sistem dapat dilengkapi menjadi full satu kitab dan dapat dikembangkan dengan menggunakan kitab syarah hadits yang lebih spesifik lainnya seperti kitab syarah Fatkhul Barri, syarah Imam An-Nawawi atau kitab syarah dari hadits shahih periwayat lain.

2. Sistem dapat dikembangkan dengan user interface yang lebih menarik dan user friendly.

3. Penerapan metode pembobotan kata dan metode similarity yang memiliki tingkat akurasi lebih tinggi.
4. Sistem dapat dikembangkan selain menggunakan manajemen database MySql, karena dengan menggunakan MySql sistem berjalan sedikit lebih lambat dikarenakan sistem harus menelusuri data yang ada sehingga waktu untuk menemukan dokumen yang relevan relatif lama.

\section{DAFTAR PUSTAKA}

[1] Zuhri, Muhammad. 2011. Hadis Nabi Telaah Historis dan Metodologis. Yogyakarta: Tiara Wacana Yogya.

[2] Rosyid, Khoirul. 2016. Kepemimpinan Menurut Hadits Nabi Saw. Skripsi. Jurusan Tafsir Hadits. Fakultas Ushuluddin. Institut Agama Islam Negeri (IAIN) Raden Intan Lampung.

[3] Mukaromah, Kholila. 2015. Kajian Syarah Hadits Subul Al-Salam. Tesis. Jurusan Studi Agama dan Filsafat. Fakultas Humaniora. Universitas Islam Negeri Sunan Kalijaga. Yogyakarta.

[4] Katsir, Ibnu. 2013. Tafsirul 'Allam Syarh 'Umdatul Ahkam. Jakarta: Ummul-Qura.

[5] Rizki, Dhidik, dan Eko Supraptono. 2017. Penerapan Algoritma Cosine Similarity dan Pembobotan TF-IDF pada Sistem Klasifikasi Dokumen. Skripsi. Jurusan Teknik Elektro. Fakultas Teknik. Universitas Negeri Semarang Kampus Sekaran, Gunungpati, Semarang.

[6] Ma'arif, Abdul Aziz. 2015. Penerapan Algoritma Tf-Idf Untuk Pencarian Karya Ilmiah. Jurnal. Jurusan Teknik Informatika. Fakultas Ilmu Komputer. Universitas Dian Nuswantoro Semarang.

[7] Rozas, I. R. dan Sarno, R. 2011. Sistem Pemilihan Kontrol Keamanan Informasi Berbasis ISO 27001. Seminar Nasional Pascasarjana XI. IT. Surabaya.

[8] Mukaromah, Kholila. 2015. Kajian Syarah Hadits Subul Al-Salam. Tesis. Jurusan Studi Agama dan Filsafat. Fakultas Humaniora. Universitas Islam Negeri Sunan Kalijaga. Yogyakarta.

[9] Katsir, Ibnu. 2013. Tafsirul 'Allam Syarh 'Umdatul Ahkam. Jakarta: Ummul-Qura.

[10] Feldman, Ronen, dan Sanger, James. 2007. The Text Mining Handbook Advanced Approaches in Analyzing Unstructured Data. New York: Cambridge University Press. 
[11] Safitri, Rima Noer. 2013. Temu Kembali Informasi Pada Pencarian Jurnal Skripsi Menggunakan Metode Single Pass Clustering. Skripsi. Universitas Muhammadiyah Gresik.

[12] Feldman, Ronen, dan Sanger, James. 2007. The Text Mining Handbook Advanced Approaches in Analyzing Unstructured Data. New York: Cambridge University Press.

[13] Rizki, Dhidik, dan Eko Supraptono. 2017. Penerapan Algoritma Cosine Similarity dan Pembobotan TF-IDF pada Sistem Klasifikasi Dokumen. Skripsi. Jurusan Teknik Elektro. Fakultas Teknik. Universitas Negeri Semarang Kampus Sekaran, Gunungpati, Semarang.

[14] Arwanda, Ivan. 2013. Penerapan Metode Text Mining pada Aplikasi Chatbot. Skripsi. Jurusan Teknik Informatika Universitas Ilmu Komputer. Bandung.

[15] Simorangkir, Manase Sahat. 2017. Studi Perbandingan Algoritma-Algoritma Stemming Untuk Dokumen Teks Bahasa Indonesia. Jurnal. Teknik Informatika. Universitas Presiden Jababeka Education.

[16] Ma'arif, Abdul Aziz. 2015. Penerapan Algoritma Tf-Idf Untuk Pencarian
Karya Ilmiah. Jurnal. Jurusan Teknik Informatika. Fakultas Ilmu Komputer. Universitas Dian Nuswantoro Semarang.

[17] Putra, Agung Auliaguntary Arif. 2016. Implementasi Text Summarization Menggunakan Metode Vector Space Model pada Artikel Berita Bahasa Indonesia. Skripsi. Jurusan Teknik Informatika. Fakultas Teknik dan Ilmu Komputer. Universitas Komputer Indonesia.

[18] Dewa, Arie, dan Agustinus. 2016. Pengukuran Kemiripan Dokumen Teks Bahasa Indonesia Menggunakan Metode Cosine Similarity. Jurnal. Teknik Informatika Universitas Sam Ratulangi Manado.

[19] Rozas, I. R. dan Sarno, R. 2011. Sistem Pemilihan Kontrol Keamanan Informasi Berbasis ISO 27001. Seminar Nasional Pascasarjana XI. IT. Surabaya.

[20] Ferdinandus, Subari. 2015. Sistem Information Retrieval Layanan Kesehatan Untuk Berobat dengan Metode Vector Space Model berbasis WebGis. Jurnal. Teknik Informatika. STIKI Malang. 